\title{
PRAKTIK AKUNTANSI MANAJEMEN DAN FAKTOR-FAKTOR KONTIJENSINYA PADA UMKM DI RUMAH KREATIF BUMN (RKB) KABUPATEN GIANYAR
}

\author{
Putu Yudha Asteria Putria,, ${ }^{*}$ I Gusti Ayu Ratih Permata Dewi ${ }^{b}$, Cok Istri \\ Ratna Sari Dewic \\ a,b,cUniversitas Warmadewa, Л. Terompong No.24, Sumerta Kelod, \\ Denpasar Tim., Kota Denpasar, Bali, Indonesia \\ *(asteriaputri@warmadewa.ac.id)
}

\begin{abstract}
ABSTRAK
Penelitian ini bertujuan untuk mengetahui sejauh mana praktik akuntansi manajemen digunakan dalam pelaksanaan Usaha Mikro, Kecil dan Menengah (UMKM) yang ada di Rumah Kreatif BUMN (RKB) Kabupaten Gianyar serta faktor-faktor kontijensinya. Terlebih lagi saat ini UMKM menjadi tulang punggung perekenomian Indonesia, yakni sebagai penyedia lapangan pekerjaan yang utama (Tambunan, 2008). Walaupun banyak hal yang menyebabkan bertahannya UMKM sebagai pelaku usaha terbesar, ada pula hal-hal yang membuat UMKM tidak dapat bertahan. Salah satunya ketidakmampuan UMKM untuk memanfaatkan alat atau praktik-praktik bisnis dan manajemen yang esensial. Penelitian ini menggunakan uji regresi linier berganda untuk mengetahui pengaruh faktor - faktor yang berpengaruh terhadap Praktek Akuntansi Manajemen. Penelitian ini menghasilkan kualifikasi staf akuntansi, persaingan pasar, ketidakpastian lingkungan, partisipasi pemilik dan ukuran perusahaan berpengaruh positif terhadap Praktek Akuntansi Manajemen.

Kata kunci: Akuntansi Manajemen, Kualifikasi Staf Akuntansi, Persaingan Pasar, Usaha Mikro, Kecil dan Menengah (UMKM)
\end{abstract}

\begin{abstract}
This study aims to determine the extent to which management accounting practices are used in the implementation of Micro, Small and Medium Enterprises (UMKM) in the Gianyar Regency BUMN Creative House (RKB) and its contingent factors. Moreover, currently UMKM are the backbone of Indonesia's economy, namely as the main provider of employment (Tambunan, 2008). Although there are many things that cause the survival of MSMEs as the biggest business actors, there are also things that make UMKM unable to survive. One of them is the inability of UMKM to utilize essential business and management tools or practices. This study uses multiple linear regression tests to determine the effect of factors that influence the Management Accounting Practice. This study resulted in accounting staff qualifications, market competition, environmental uncertainty, owner participation and company size positively influencing Management Accounting Practices.
\end{abstract}

Keywords: Management Accounting, Accounting Staff Qualifications, Market Competition, Micro, Small and Medium Enterprises (UMKM) 
PENDAHULUAN

Di era globalisasi yang berkembang saat ini, persaingan dalam dunia kerja (Tambunan, 2008). Pada tahun 2015 UMKM merupakan pelaku usaha terbesar di Indonesia, yakni 56,5 juta usaha atau 99,9\% dari total pelaku usaha nasional. Dari jumlah tersebut UKM dapat menyerap tenaga kerja 97,3\% dari total jumlah tenaga kerja di Indonesia (Marta, 2016). Selain itu, pada tahun yang sama UMKM memberi kontribusi 60,34\% terhadap total PDB nasional (Mutmainah, 2016). Melalui sektor usaha ini telah terbukti kemampuannya dalam bertahan dan meningkatkan kinerja perekonomian saat krisis ekonomi melanda Indonesia pada akhir tahun 1990-an. Hal itu disebabkan UMKM memiliki fleksibilitas dalam beradaptasi dan dapat terus berkembang meski harus menggunakan modal sendiri, membayar bunga yang tinggi, dan hanya mendapatkan sedikit perhatian dari pemerintah (Hamdani dan Wirawan, 2012).

Walaupun banyak hal yang menyebabkan bertahannya UMKM sebagai pelaku usaha terbesar, ada pula hal-hal yang membuat UMKM tidak dapat bertahan. Salah satunya ketidakmampuan UMKM untuk memanfaatkan alat atau praktik- praktik bisnis dan manajemen yang esensial (Nandan, 2010; Ahmad, 2012). Padahal sebenarnya jika dilakukan perencanaan secara formal akan dapat mengurangi kemungkinan gagalnya suatu UMKM. Hopper et al. (1999) menyebutkan bahwa salah satu faktor penyebab tingginya tingkat kegagalan UMKM yakni tidak digunakannya salah satu praktikpraktik akuntansi manajamen (selanjutnya disebut PAM), yakni sistem manajemen biaya, sebagai suatu bentuk pengendalian yang lebih berorientasi pada laba. Pada UMKM, PAM berperan sebagai sistem informasi yang mengolah informasi secara efisien. Selain itu, informasi keuangan dan nonkeuangan yang dihasilkan oleh PAM dapat meningkatkan daya saing serta membantu dalam menghadapi berbagai perubahan yang dialami perusahaan sehingga dapat meningkatkan kinerja (Reid dan Smith, 2002). Penggunaan PAM tidak serta-merta menjamin kesuksesan, tetapi tidak menggunakannya berarti mengurangi keunggulan kompetitif suatu perusahaan (Folk et al. 2002). Penggunaan PAM dapat membantu UMKM dalam mengelola sumber daya yang dimiliki sehingga dapat meningkatkan nilai yang diberikan kepada kustomer dan pemilik/pengelola (Nandan, 2010). 
Perkembangan potensi Usaha Mikro, Kecil dan Menengah (UMKM) di Indonesia tidak terlepas dari dukungan perbankan dalam penyaluran kredit kepada UMKM. Setiap tahun kredit kepada UMKM mengalami pertumbuhannya lebih tinggi dibanding total kredit perbankan. Jumlah pelaku usaha industri UMKM Indonesia termasuk paling banyak diantara negara lainnya, terutama sejak tahun 2014. Terus mengalami perkembangan sehingga diperkirakan hingga akhir tahun nanti jumlah pelaku UMKM di Indonesia akan terus mengalami pertumbuhan. Menyadari pentingnya kontribusi UMKM dalam meningkatkan perekonomian yang positif di Indonesia, salah satu Bank BUMN telah bersinergi untuk mendorong peningkatan UMKM di Indonesia. PT Bank Rakyat Indonesia (BRI) Tbk. berkomitmen untuk mendukung aktivitas para pelaku UMKM Indonesia. Bukan hanya memberikan fasilitas kredit dengan suku bunga yang rendah kepada para pelaku UMKM, PT. Bank Rakyat Indonesia (BRI) Tbk. terus memperkuat dukungannya dalam mendorong dan memajukan sektor Usaha Mikro, Kecil, dan Menengah (UMKM) di Indonesia dengan menghadirkan secara langsung Rumah Kreatif BUMN (RKB) salah satunya di Kabupaten Gianyar, Bali yang saat ini tercatat memiliki paling banyak sektor UMKM dengan jumlah 91.511 UMKM dan RKB yang dibangun oleh BRI di Kabupaten Gianyar, Bali telah memiliki anggota 168 pelaku UMKM di wilayah Gianyar, Sukawati, Ubud, dan sekitarnya.

Sebagian besar penelitian yang ada mengenai penggunaan PAM pada UKM dilakukan di negara-negara maju, dan sedikit sekali penelitian yang dilakukan di negara-negara berkembang, seperti Indonesia (lihat Sousa et al., 2006; McChlery et al., 2005; Armitage et al., 2016). Lebih jauh lagi, keberhasilan penerapan suatu PAM akan bergantung pada faktor-faktor kontinjensinya, seperti faktor organisasional dan karakteristik lingkungan bisnis (Miles dan Snow, 1978; Tillema, 2005).

Mengingat pentingnya peranan sektor UMKM bagi perekonomian Indonesia dan masih sedikit penelitian yang berfokus pada sektor ini, penelitian ini bertujuan untuk menunjukkan seberapa jauh pengimplementasian PAM pada sektor UMKM di Indonesia dan faktor faktor kontinjensi yang memengaruhi pengimplementasian PAM.. Secara spesifik, penelitian ini diharapkan dapat memberi beberapa kontribusi. Dimana pada nantinya hasil 
penelitian ini diharapkan dapat memberikan manfaat bagi pelaku UMKM dan akuntan/auditor eksternal, pembuat kebijakan, dan akademisi tentang kemajuan dan faktor-faktor kontinjensi yang memengaruhi pengaplikasian PAM pada sektor UMKM khususnya di Bali.

\section{TELAAH LITERATUR DAN PERUMUSAN HIPOTESIS}

\section{Akuntansi Manajemen}

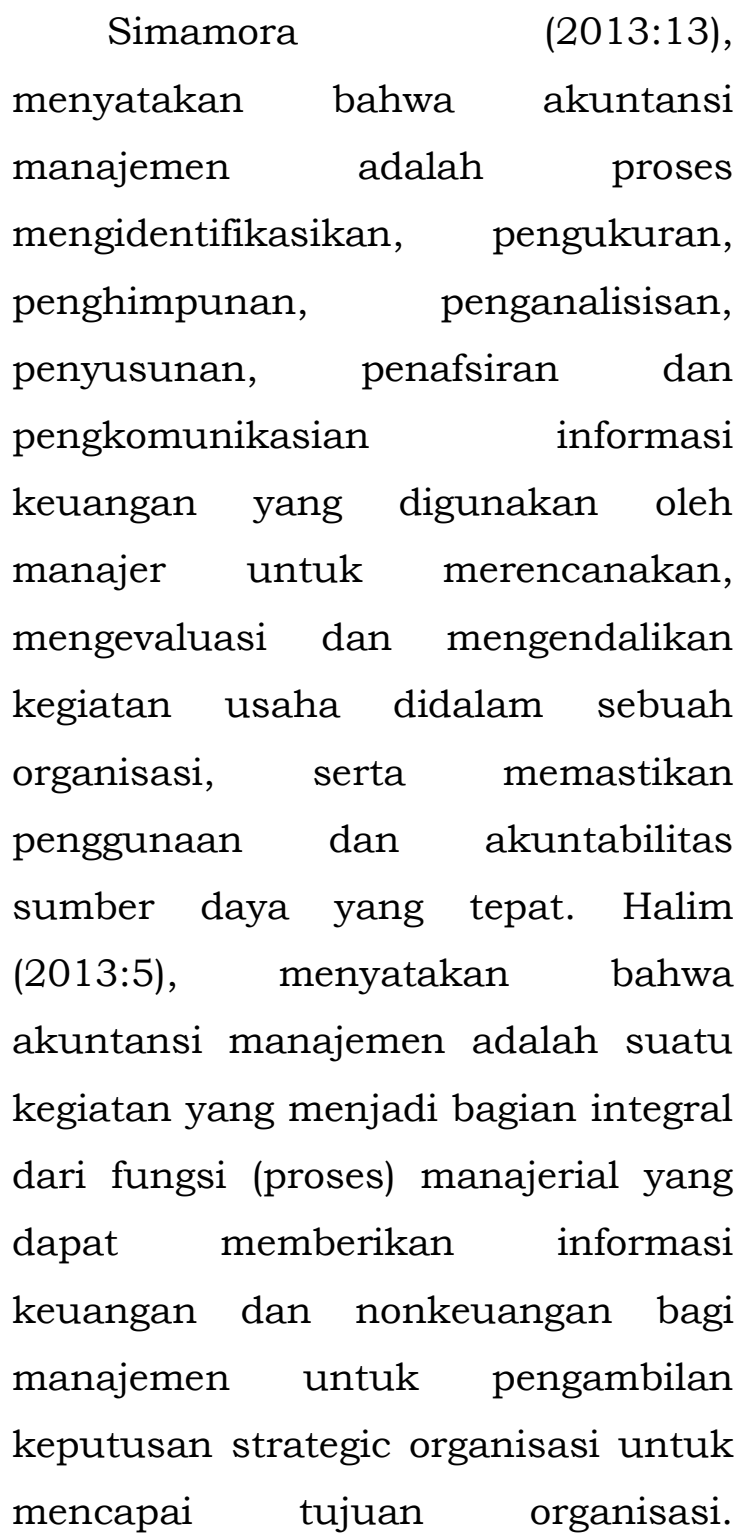

Kamaruddin (2013:5), menyatakan bahwa akuntansi manajemen adalah penerapan teknik dan konsep yang tepat dalam pengolahan data ekonomi historikal dan yang diproyeksikan dari suatu satuan usaha untuk membantu manajemen dalam penyusunan rencana untuk tujuan ekonomi yang rasional dan dalam membuat keputusan rasional dengan suatu pandangan kearah pencapaian tujuan tersebut.

\section{Usaha Mikro, Kecil dan Menengah}

Menurut Undang-Undang
Republik Indonesia No. 20 tahun 2008 Pasal 1, yang dimaksud dengan:

1) Usaha Mikro adalah usaha produktif milik orang perorangan dan/atau badan usaha perorangan yang memenuhi kriteria usaha mikro sebagaimana diatur dalam undang-undang ini.

2) Usaha Kecil adalah usaha ekonomi produktif yang berdiri sendiri, yang dilakukan oleh orang perorangan atau badan usaha yang bukan merupakan anak perusahaan atau bukan cabang perusahaan yang dimiliki, dikuasai, atau menjadi bagian baik langsung maupun tidak langsung dari usaha menengah atau usaha besar yang memenuhi kriteria usaha kecil sebagaimana diatur dalam undang-undang ini. 
3) Usaha Menengah adalah usaha ekonomi produktif yang berdiri sendiri, yang dilakukan oleh orang perorangan atau badan usaha yang bukan merupakan anak perusahaan atau bukan cabang perusahaan yang dimiliki, dikuasai, atau menjadi bagian baik langsung maupun tidak langsung dari usaha kecil atau usaha besar dengan jumlah kekayaan bersihatau hasil penjualan tahunan sebagaimana diatur dalam undang-undang ini.

4) Usaha mikro sebagaimana dimaksud menurut keputusan Menteri Keuangan No. 40/KMK.06/2003 tanggal 29 Januari 2003, yaitu usaha produktifmilik keluarga atau perorangan Warga Negara Indonesia dan memiliki hasil penjualan paling banyak $\mathrm{Rp}$. 100.000.000,-- (seratus juta rupiah) per tahun.

\section{Ketidakpastian Lingkungan}

Ketidakpastian lingkungan merupakan salah satu faktor yang sering menyebabkan organisasi melakukan penyesuaian terhadap kondisi organisasi dengan lingkungan. Dalam teori institusional, organisasi ditekan menjadi semakin sama, kadangkadang karena kendala lingkungan (DiMaggio dan Powell 1983 dalam Ridha, 2012). Dalam kondisi ketidakpastian lingkungan yang tinggi, informasi akan sangat berguna dalam proses kegiatan perencanaan dan kontrol dalam suatu organisasi. Sistem akuntansi yang andal akan memudahkan penyediaan informasi yang tepat waktu dan relevan, dimana para manajer memiliki kebutuhan informasi yang berbeda (Wiryana 2014).

\section{Persaingan Pasar}

Persaingan pasar sebuah industri usaha kecil dan menegah sangat bergantung pada tingkat produk yang berkembang dari kualitas produk yang ditawarkan kepada konsumen. Banyaknya pesaing dalam usah kecil dan menengah menjadikan perusahaan harus berfikir untuk memajukan strategi pemasaran yang lebih baik dan efektif. Dengan begitu, strategi pemasaran yang lebih baik akan menghasilkan profit yang baik juga bagi usaha tersebut.

Perusahaan yang menghadapi persaingan pasar yang relatif intens akan cenderungmemiliki produk atau jasa yang menghasilkan margin laba rendah karena tekanan untuk menyamai atau bahkan menurunkan harga jual lebih rendah dari harga yang ditetapkan pesaingnya (A1-Omiry dan Drury, 2007). Pada keadaan tersebut sangat dibutuhkan sistem biaya yang akurat karena sistem 
biaya yang tidak akurat akan menyebabkan biaya produk/jasa menjadi lebih tinggi atau lebih rendah dari yang seharusnya. Penentuan biaya produk/jasa yang lebih rendah (undercosting) dapat menyebabkan perusahaan terus menjual produk yang sebenarnya memberikan laba rendah sehingga perusahaan mengalami kerugian. Apabila sistem biaya produk lebih tinggi (overcosting) akan menyebabkan penghentian produk yang dilaporkan menghasilkan kerugian, yang sebenarnya memberikan laba tinggi.

\section{Kualifikasi Staf Internal}

Beberapa

penelitian

mengungkapkan bahwa karakteristik dari staf kunci yang dimiliki UMKM akan memengaruhi penggunaan PAM. Keberadaan staf akuntansi internal yang berkualifikasi dapat memengaruhi secara signifikan pengadopsian PAM (Lopez dan Hiebl, 2015). Akan tetapi, keterbatasan sumber daya yang dimiliki akan menyebabkan UKM tidak memiliki staf akuntansi internal atau bila ada, staf akuntansi tersebut tidak memiliki kualifikasi yang sesuai, tidak memiliki pelatihan yang mencukupi, atau tidak termotivasi untuk melakukan inovasi, akan mengurangi kemungkinan pengadopsian PAM (McChlery et al., 2005). Staf akuntansi diharuskan memiliki beberapa tanggung jawab dan peran secara bersamaan, tidak hanya berfokus pada satu area manajerial. Hal tersebut menyebabkan staf tidak memiliki pelatihan yang cukup untuk mengadopsi PAM yang kontemporer (Lopez dan Hiebl, 2015).

\section{Partisipasi Pemilik}

Penelitian yang dilakukan oleh Ahmad (2012) menyebutkan bahwa partisipasi pemilik atau manajer memiliki hubungan positif dengan penggunaan anggaran, PAM yang berhubungan dengan pengambilan keputusan untuk jangka pendek serta perencanaan dan pengembangan strategi. Hal tersebut karena pada UMKKM, pemilik atau manajer berperan sebagai pengambil keputusan yang paling utama dan pada umumnya merupakan penentu masa depan perusahaan. Oleh karena itu, pemilik atau manajer yang memiliki rasa tanggung jawab dan komitmen yang tinggi terhadap perusahaan mereka akan mendorong penggunaan PAM yang memberi informasi yang tepat sehingga dapat membantu dalam peningkatan kinerja perusahaan. Jika pemilik atau manajer menganggap akuntansi manajemen hanya sebagai penyedia informasi untuk institusi eksternal (contohnya bank), akuntansi manajemen tidak akan digunakan untuk pengambilan keputusan (Lopez 
dan Hiebl, 2015). Selain itu, pemilik atau manajer memiliki wewenang mengalokasikan sumber daya yang dibutuhkan untuk pengadopsian PAM (Ismail dan King, 2007).

\section{Ukuran Perusahaan}

Pada umumnya perusahaan yang berukuran lebih besar menggunakan PAM lebih banyak macamnya dan lebih kontemporer dibandingkan dengan perusahaan kecil. Perusahaan yang lebih besar memiliki sumber daya yang lebih besar dan sistem komunikasi internal yang lebih baik sehingga dapat memfasilitasi pengimplementasian PAM (Abdel-Kader dan Luther, 2008). Perusahaan yang berukuran lebih besar juga memiliki proses bisnis yang lebih kompleks sehingga memiliki tantangan yang lebih sulit. Oleh karena itu, perusahaan yang berukuran lebih besar membutuhkan pengendalian dan informasi yang lebih banyak mengenai aktivitasnya sehingga membutuhkan PAM yang komprehensif dan kontemporer (Chenhall, 2003).

\section{Kerangka Penelitian}

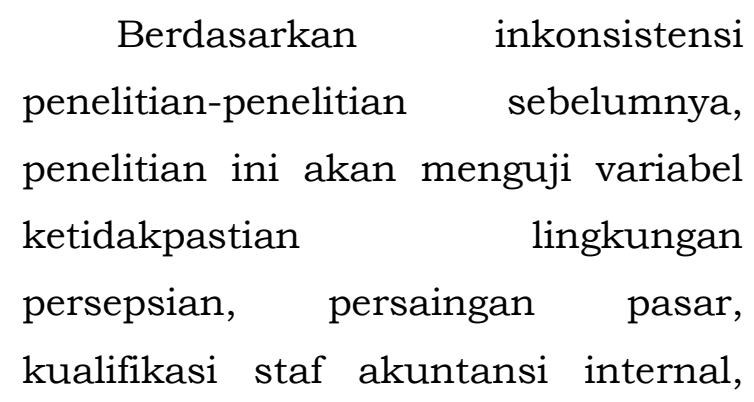

partisipasi pemilik atau manajer dan ukuran perusahaan terhadap praktik akuntansi manajemen di RKB BRI Kabupaten Gianyar.

\section{Ketidakpastian Lingkungan dan}

Praktik Akuntansi Manajemen

Lingkungan eksternal yang bersifat tidak pasti yang dihadapi UKM dapat diantisipasi dan dikendalikan melalui mekanisme internal, yaitu salah satunya dengan menggunakan PAM kontemporer. Hasil ini sesuai dengan penelitian yang dilakukan oleh Marn et al. (2016). Marn et al. menyatakan bahwa tingkat ketidakpastian lingkungan memengaruhi secara positif pengadopsian perencanaan strategik pada UMKM. Semakin tinggi tingkat ketidakpastian lingkungan, UMKM harus semakin meningkatkan proses perencanaan strategik.

Berdasarkan penelitian sebelumnya maka penulis mengajukan hipotesis pertama sebagai berikut :

H1: Ketidakpastian Lingkungan berpengaruh positif terhadap praktik akuntansi manajemen.

\section{Persaingan Pasar dan Praktik} Akuntansi Manajemen

Tingkat persaingan yang tinggi memaksa UMKM untuk mendedikasikan seluruh sumber daya 
yang dimiliki (waktu, uang, dan manusia) untuk menghadapi persaingan pasar tersebut, bukan untuk mengimplementasi teknikteknik manajemen yang inovatif. Alasan ini didukung oleh temuan Marc et al. (2010) yang menunjukkan bahwa 50\% UMKM yang tidak mengimplementasikan BSC karena UMKM tidak memahami konsep dan $18 \%$ karena biaya implementasi yang tinggi.

Berdasarkan

penelitian sebelumnya maka penulis mengajukan hipotesis kedua sebagai berikut:

H2: Persaingan pasar berpengaruh positif terhadap praktik akuntansi manajemen

\section{Kualifikasi Staff dan Praktik}

\section{Akuntansi Manajemen}

Praktik-praktik akuntansi manajemen merupakan salah satu sumber dari informasi keuangan. Berdasarkan Collis dan Jarvis (2002), staf akuntansi internal yang berkualifikasi dan memiliki tingkat pendidikan dan pelatihan mengenai akuntansi yang tinggi akan dapat membantu pengembangan sistem akuntansi manajemen serta analisis dari informasi akuntansi yang dihasilkan oleh sistem tersebut.

Berdasarkan penelitian sebelumnya maka muncul hipotesis ketiga sebagai berikut :
H3: Kualifikasi staf akuntansi berpengaruh positif terhadap praktik akuntansi manajemen

\section{Partisipasi Pemilik dan Praktik} Akuntansi Manajemen

Sebagian besar UMKM dimulai dari usaha wiraswasta sehingga pemilik atau manajer memiliki peran utama dalam menentukan kebijakan inovasi UMKM, misalnya dalam pengimplementasian sistem informasi akuntansi. Oleh karena itu, pemilik atau manajer yang berkomitmen merupakan penentu gaya manajemen perusahaan dan penggunaan PAM terbaik yang dapat memberikan informasi manajerial yang tepat, guna membantu pencapaian tujuan strategic perusahaan (Thong et al., 1996). Hal tersebut didukung oleh temuan Ahmad (2012) yang menyebutkan bahwa partisipasi pemilik atau manajer UMKM berpengaruh signifikan dan positif terhadap penggunaan anggaran, sistem pengambilan keputusan, akuntansi manajemen strategik, perencanaan dan pengendalian terutama pada pengembangan strategi.

Berdasarkan penelitian sebelumnya maka muncul hipotesis keempat sebagai berikut :

H4: Partisipasi pemilik berpengaruh positif terhadap praktik akuntansi manajemen 
Ukuran Perusahaan dan Praktik Akuntansi Manajemen

Ahmad (2012) menyebutkan bahwa ukuran perusahaan berhubungan positif dan signifikan dengan penggunaan sistem biaya dan sistem penilaian kinerja pada UMKM. Marc et al. (2010) juga menyebutkan bahwa semakin besar ukuran suatu perusahaan, semakin besar pula kemungkinan UMKM tersebut untuk menggunakan sistem penilaian kinerja terintegrasi. Marc et al. (2010) juga menemukan bila suatu UMKM telah mencapai suatu ukuran tertentu, peningkatan pada ukurannya tidak akan lagi memengaruhi penggunaan sistem penilaian kinerja. Abdel-Kader dan Luther (2008) menemukan bahwa perbedaan pada tingkat kemajuan akuntansi manajemen yang digunakan perusahaan dapat dijelaskan dengan ukuran perusahaan yang bersangkutan. Hansen dan Van der Stede (2004) juga melaporkan bahwa ukuran perusahaan mendorong penggunaan anggaran yang bertujuan untuk penilaian kinerja dan pengomunikasian tujuan perusahaan.

Berdasarkan penelitian sebelumnya maka muncul hipotesis ketiga sebagai berikut :
H5: Ukuran perusahaan berpengaruh positif terhadap praktik akuntansi manajemen

\section{METODE}

Berdasarkan hipotesis penelitian, variabel-variabel yang digunakan dalam penelitian adalah ketidakpastian lingkungan persepsian, persaingan pasar, kualifikasi staf akuntansi internal, partisipasi pemilik atau manajer, ukuran perusahaan dan praktikpraktik akuntansi manajemen. Pengumpulan data yang digunakan dalam penelitian ini meliputi: observasi, wawancara dan penyebaran kuisioner kepada pelaku UMKM di Kabupaten Gianyar

Populasi dalam penelitian ini adalah seluruh UMKM yang ada di RKB Kabupaten Gianyar yang berjumlah 22.000. Dalam penelitian ini penulis mempersempit populasi yaitu jumlah UMKM sebanyak 22.000 dengan menghitung ukuran sampel yang dilakukan dengan menggunakan teknik Slovin menurut Sugiyono (2011:87). Adapun penelitian ini menggunakan rumus Slovin karena dalam penarikan sampel, jumlahnya harus representative agar hasil penelitian dapat digeneralisasikan dan perhitungannya pun tidak memerlukan tabel jumlah sampel, namun dapat dilakukan dengan 
rumus dan perhitungan sederhana. Rumus Slovin untuk menentukan sampel adalah sebagai berikut :

$$
\mathbf{n}=\frac{N}{1+N(e)^{2}}
$$

Keterangan:

$\mathrm{n}=$ Ukuran sampel/jumlah responden

$\mathrm{N}=$ Ukuran populasi
$\mathrm{E}=$ Presentase kelonggaran ketelitian kesalahan pengambilan sampel yang masih bisa ditolerir; $\mathrm{e}=0,1$

Berikut perhitungan sampel dengan menggunakan rumus slovin:

$$
\begin{aligned}
& \mathrm{n}=\frac{22.000}{1+22.000(0.1)^{2}} \\
& \mathrm{n}=99,54 \text { sampel, dibulatkan }
\end{aligned}
$$
menjadi 100 sampel keseluruhan

Tabel 1. Jumlah UMKM per Kategori Usaha

\begin{tabular}{llc}
\hline No & Nama UMKM & Jumlah UMKM \\
\hline 1 & Fashion/Busana & 341 \\
2 & Makanan dan Minuman & 271 \\
3 & Craft/Kerajinan Tangan & 138 \\
4 & Industri & 145 \\
5 & Perdagangan & 19.617 \\
6 & Pertanian & 128 \\
7 & Peternakan & 192 \\
8 & Perkebunan & 5 \\
9 & Perikanan & 3 \\
10 & Jasa & 221 \\
11 & Lainnya & 939 \\
& Total & 22.000
\end{tabular}

Sumber: http://panel.rkb.id/rkb/

\section{HASIL DAN PEMBAHASAN}

\section{Statistik Deskriptif}

Statistik deskriptif merupakan teknik deskriptif yang memberikan informasi mengenai data yang dimiliki dan tidak bermaksud menguji hipotesis. Statistik deskriptif disajikan untuk memberikan informasi mengenai jumlah sampel, nilai minimum, nilai maksimum, nilai rata-rata, dan standar deviasi dari masing-masing variabel. Berdasarkan data olahan SPSS yang meliputi Praktik Akuntansi Manajemen, ketidakpastian lingkungan persepsian, persaingan pasar, kualifikasi staf akuntansi internal, partisipasi pemilik atau manajer dan 
ukuran perusahaan maka akan dapat diketahui nilai maksimum, nilai minimum, nilai rata-rata, dan standar deviasi dari setiap variabel. Berikut hasil statistik deskriptif dapat dilihat dalam Tabel 2

Tabel 2 Hasil Statistik Deskriptif

\begin{tabular}{cccccc}
\hline & N & Minimum & Maximum & Mean & Std. Deviation \\
\hline Y & 100 & 53,36 & 166,27 & 128,6655 & 40,99714 \\
X1 & 100 & 6,00 & 22,28 & 16,5675 & 5,46780 \\
X2 & 100 & 1,00 & 3,71 & 2,7341 & 1,00093 \\
X3 & 100 & 1,00 & 3,65 & 2,7407 & 1,00047 \\
X4 & 100 & 1,00 & 3,68 & 2,7508 & 0,99980 \\
X5 & 100 & 0,00 & 1,00 & 0,6500 & 0,47937 \\
Valid N & 100 & & & & \\
(listwise) & & & & & \\
\hline
\end{tabular}

Sumber: Data diolah (2018)

Rata-rata (Mean) digunakan untuk mengukur nilai sentral dari suatu distribusi data, sedangkan standar deviasi digunakan untuk mengukur perbedaan nilai data yang diteliti dengan nilai rata-ratanya. Tabel 5.2 menunjukkan bahwa Mean variabel praktik akuntansi manajemen adalah 128,66 dengan standar deviasi sebesar 40,99. Mean variabel ketidakpastian lingkungan adalah 16,56 dengan standar deviasi sebesar 5,46. Mean variabel persaingan pasar adalah 2,73 dengan standar deviasi sebesar 1,00. Mean variabel kualifikasi staf akuntansi internal adalah 2,74 dengan standar deviasi sebesar 1,00. Mean variabel partisipasi pemilik atau manager adalah 2,75 dengan standar deviasi sebesar 0,99. Mean variabel ukuran perusahaan adalah 0,65 dengan standar deviasi sebesar 0,47. Hasil ini juga menunjukkan bahwa nilai sentral dari distribusi data dengan nilai tertinggi adalah praktik akuntansi manajemen dan yang terendah adalah ukuran perusahaan. Selain itu, variabel yang memiliki standar deviasi tertinggi adalah praktik akuntansi manajemen dan yang terendah adalah ukuran perusahaan

\section{Uji Kualitas Data}

Hair et al., (1998) menjelaskan bahwa dalam penelitian, kualitas data yang dihasilkan dari penggunaan instrumen dapat dianalisis dengan menggunakan pengujian validitas dan reliabilitas. Pengujian kualitas data 
dapat dilihat pada sub bagian berikut ini :

\section{Uji Validitas}

Uji validitas digunakan untuk mengukur sah atau valid tidaknya suatu kuesioner. Suatu kuesioner dikatakan valid jika pertanyaan pada kuesioner mampu untuk mengungkapkan sesuatu yang akan diukur oleh kuesioner tersebut. Dalam penelitian ini untuk mengukur validitas digunakan Coeficient corelation pearson yaitu dengan menghitung korelasi antara skor masing-masing butir pertanyaan dengan total skor, Ghozali (2001). Untuk tingkat validitas dilakukan uji signifikansi dengan membandingkan nilai $r$ hitung dengan nilai $r$ tabel. Untuk degree of freedom (df) $=n-k$ dalam hal ini $\mathrm{n}$ adalah jumlah sampel dan k adalah jumlah konstruk.

Pada kasus ini besarnya df dapat dihitung 100-8 atau df = 92 dengan alpha 0,05 didapat $r$ tabel 0,202; jika $r$ hitung (untuk tiap-tiap butir pertanyaan dapat dilihat pada kolom corrected item pertanyaan total correlation) lebih besar dari $r$ tabel dan nilai $r$ positif, maka butir pertanyaan tersebut dikatakan valid. Hasil pengujian dengan menggunaan program SPSS menunjukkan nilai Coeficient correlation pearson pada masing-masing variabel bernilai $>0,8$.

\section{Uji Reliabilitas}

Instrumen dikatakan reliabel apabila memiliki koefisien Cronbach Alpha lebih besar dari 0,70 (Ghozali, 2011). Hasil penelitian pada Tabel 3 menunujukan seluruh nilai koefisien Cronbach Alpha dari instrumen ini lebih besar dari 0,70, sehingga instrumen dari penelitian ini dapat dikatakan reliabel atau bila instrumen ini digunakan beberapa kali untuk mengukur suatu objek yang sama, akan menghasilkan data yang sama pula.

\section{Uji Regresi Linier Berganda}

Setelah semua uji asumsi klasik terpenuhi maka tahap selanjutnya adalah melakukan uji regresi linear berganda dengan model dasar sebagai berikut:

$$
\begin{array}{r}
Y=a+\beta 1 X_{1}+\beta_{2} X_{2}+\beta_{2} X_{2}+ \\
\beta_{3} X_{3}+\beta_{3} X_{3}+\beta_{4} X_{4}+\beta_{5} X_{5}+\varepsilon
\end{array}
$$

Keterangan:

$\mathrm{Y}=$ Praktik Akuntansi Manajemen

$\mathrm{a}=$ Konstanta

$\beta 1-\beta 5=$ Koefisien Regresi

$\mathrm{X} 1=$ Ketidakpastian

Lingkungan

$\begin{array}{lll}\mathrm{X} 2 & =\text { Persaingan Pasar } \\ \mathrm{X} 3 & =\quad \text { Kualifikasi Staf }\end{array}$

Akuntansi Internal

$$
\begin{aligned}
& \text { X4 = Partisipasi Pemilik } \\
& \text { X5 } \quad=\text { Ukuran Perusahaan } \\
& \varepsilon=\text { Faktor lain yang berpengaruh }
\end{aligned}
$$
terhadap variabel terikat $(\mathrm{Y})$ 
Tabel 3 Hasil Uji Reliabilitas

\begin{tabular}{llcc}
\hline \multicolumn{1}{c}{ No. } & Variabel & $\begin{array}{c}\text { Koefisien } \\
\text { Cronbach Alpha }\end{array}$ & Keterangan \\
\hline 1 & Ketidakpastian Lingkungan (X1) & 0,950 & Reliabel \\
2 & Persaingan Pasar (X2) & 0,954 & Reliabel \\
& Kualifikasi Staf Akuntansi Internal (X3) & 0,946 & Reliabel \\
& (X2b) & 0,949 & Reliabel \\
4 & Partisipasi Pemilik (X4) & 0,950 & Reliabel \\
5 & Ukuran Perusahaan (X5) & 0,994 & Reliabel \\
6 & Praktik Akuntansi Manajemen (Y) & &
\end{tabular}

Sumber: Data diolah (2018)

Hasil uji regresi linear Kualifikasi Staf Akuntansi Internal, berganda dapat dilihat pada Tabel 4 Partisipasi Pemilik, Ukuran Pengujian tersebut dilakukan Perusahaan pada Praktik Akuntansi terhadap variabel Ketidakpastian Manajemen.

Lingkungan, Persaingan Pasar,

Tabel 5 Hasil Uji Regresi Linear Berganda

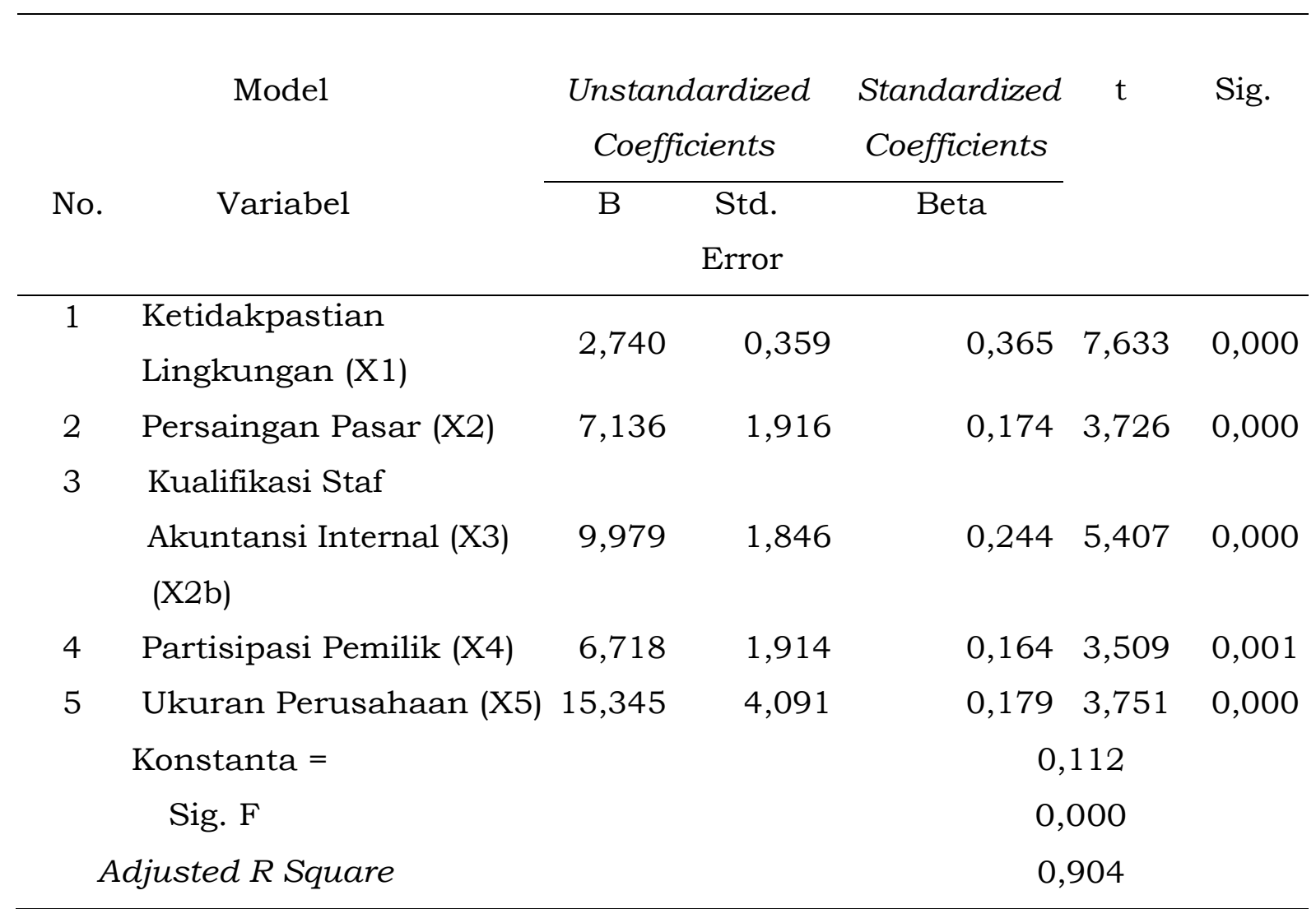

Sumber: Data diolah (2018) 
Berdasarkan hasil analisis regresi linear berganda yang ditunjukan pada Tabel 5, maka dapat dibuat persamaan regresi sebagai berikut:

$$
\begin{aligned}
& Y=0,112+0,365 X_{1}+0,174 X_{2}+ \\
& 0,244 X_{3}+0,164 X_{4}-0,179 X_{5}+\varepsilon
\end{aligned}
$$

Koefisien persamaan regresi di atas mengindikasikan bahwa variabel ketidakpastian lingkungan, persaingan pasar, kualifikasi staf akuntansi internal, partisipasi pemilik dan ukuran perusahaan memiliki pengaruh searah dengan variabel terikat yaitu praktik akuntansi manajemen. Selain itu, hasil regresi juga menunjukkan Adjusted $R$ Square sebesar 0,904. Hal tersebut menunjukkan bahwa variabilitas variabel praktik akuntansi manajemen dapat dijelaskan oleh variabel ketidakpastian lingkungan, persaingan pasar, kualifikasi staf akuntansi internal, partisipasi pemilik dan ukuran perusahaan sebesar 90,4\% persen, sedangkan sisanya sebesar 9,6 persen dijelaskan oleh variabel-variabel lain di luar model penelitian.

Nilai koefisien regresi variabel ketidakpastian lingkungan (X1) sebesar 0,365, persaingan pasar (X2) sebesar 0,174, persaingan staff akuntansi internal (X3) sebesar 0,244, partisipasi pemilik (X4) sebesar 0,164, dan ukuran perusahaan (X5) sebesar 0,179. Hasil tersebut menunjukkan bahwa variabel ketidakpastian lingkungan, persaingan pasar, kualifikasi staf akuntansi internal, partisipasi pemilik dan ukuran perusahaan berpengaruh positif pada praktik akuntansi manajemen di RKB BRI Kabupaten Gianyar.

\section{Uji Statistik F}

Hasil uji $\mathrm{F}$ atau uji kelayakan model pada Tabel 5 menunjukkan pengaruh seluruh variabel bebas terhadap variabel terikat. Uji ini dilakukan sebelum melakukan pengujian terhadap hipotesis. Apabila uji $F$ menunjukkan hasil yang signifikan, maka seluruh variabel bebas mempengaruhi variabel terikat dan model yang digunakan layak uji, sehingga pengujian hipotesis dapat dilanjutkan.

Tingkat probabilitas (sig.) $\mathrm{F}$ adalah $0,000 \leq \mathrm{a}=0,05 ; \mathrm{H} 1$ diterima dan Ho ditolak, Hasil penelitian menunjukkan nilai signifikasi $F$ sebesar 0,000 lebih kecil dari $\mathrm{a}=$ 0,05, sehingga dapat disimpulkan bahwa variable ketidakpastian lingkungan, persaingan pasar, kualifikasi staf akuntansi internal, partisipasi pemilik dan ukuran perusahaan mampu memprediksi dan menjelaskan praktik akuntansi 
manajemen di RKB BRI Kabupaten Gianyar.

\section{Uji Statistik t}

Hasil uji $t$ pada Tabel 5 menunjukkan pengaruh variabel ketidakpastian lingkungan, persaingan pasar, kualifikasi staf akuntansi internal, partisipasi pemilik dan ukuran perusahaan pada praktik akuntansi manajemen di RKB BRI Kabupaten Gianyar secara parsial. Pengujian masingmasing variabel bebas pada variabel terikat dijelaskan sebagai berikut.

$$
\text { Hipotesis pertama }
$$

menyatakan bahwa ketidakpastian lingkungan berpengaruh positif pada praktik akuntansi manajemen di RKB BRI Kabupaten Gianyar. Pengujian terhadap pengaruh ketidakpastian lingkungan pada praktik akuntansi manajemen dilakukan dengan melihat hasil uji statistik t. Tingkat probabilitas (sig.) t variabel pengalaman adalah $0,000<a$ $=0,05$. Hal ini menunjukkan bahwa $\mathrm{H}_{1}$ diterima dan $\mathrm{H}_{0}$ ditolak. Kesimpulannya adalah ketidakpastian lingkungan berpengaruh positif pada praktik akuntansi manajemen di RKB BRI Kabupaten Gianyar. Lingkungan eksternal yang bersifat tidak pasti yang dihadapi UKM dapat diantisipasi dan dikendalikan melalui mekanisme internal, yaitu salah satunya dengan menggunakan PAM kontemporer.

Hasil ini sesuai dengan penelitian yang dilakukan oleh Marn et al. (2016). Marn et al. menyatakan bahwa tingkat ketidakpastian lingkungan memengaruhi secara positif pengadopsian perencanaan strategik pada UMKM. Semakin tinggi tingkat ketidakpastian lingkungan, UMKM harus semakin meningkatkan proses perencanaan strategik. Lingkungan industri dan ekonomi akan berdampak pada tingkat ketidakpastian yang dihadapi UKM karena keterbatasan sumber daya yang dimiliki. Oleh karena itu, UKM harus menerapkan proses perencanaan yang proaktif dalam menghadapi ketidakpastian tersebut (Marn et al., 2016). Gul (1991) mengemukakan bahwa pengaruh sistem akuntansi manajemen terhadap kinerja UMKM bergantung pada tingkat ketidakpastian lingkungan. Bila tingkat ketidakpastian lingkungan tinggi, penggunaan sistem akuntansi manajemen yang kontemporer akan berpengaruh positif terhadap kinerja UMKM. Akan tetapi, bila tingkat ketidakpastian lingkungan rendah, penggunaan sistem akuntansi manajemen yang kontemporer hanya akan menghambat kinerja UMKM. 
Hipotesis kedua $\left(\mathrm{H}_{2}\right)$ menyatakan bahwa persaingan pasar berpengaruh positif pada praktik akuntansi manajemen di RKB BRI Kabupaten Gianyar. Pengujian terhadap pengaruh persaingan pasar pada praktik akuntansi manajemen dilakukan dengan melihat hasil uji statistik t. Tingkat probabilitas (sig.) t variabel pengalaman adalah $0,000<a=0,05$. $\mathrm{Hal}$ ini menunjukkan bahwa $\mathrm{H}_{2}$ diterima dan $\mathrm{H}_{0}$ ditolak. Kesimpulannya adalah persaingan pasar berpengaruh positif pada praktik akuntansi manajemen di RKB BRI Kabupaten Gianyar. Tingkat persaingan yang tinggi memaksa UMKM untuk mendedikasikan seluruh sumber daya yang dimiliki (waktu, uang, dan manusia) untuk menghadapi persaingan pasar tersebut, bukan untuk mengimplementasi teknikteknik manajemen yang inovatif. Alasan ini didukung oleh temuan Marc et al. (2010) yang menunjukkan bahwa 50\% UMKM yang tidak mengimplementasikan BSC karena UMKM tidak memahami konsep dan $18 \%$ karena biaya implementasi yang tinggi. Kedua, sampel penelitian berasal dari basis yang sama atau sempit. Ukuran perusahaan dari sampel penelitian kurang bervariasi sehingga dapat dimungkinkan UMKM mengalami lingkungan eksternal, berupa ketidakpastian lingkungan pasar dan persaingan pasar yang mirip sehingga data yang terkumpul tidak cukup untuk menghasilkan hubungan yang signifikan secara statistik (Ahmad, 2012).

$$
\text { Hipotesis ketiga }
$$

menyatakan bahwa kualifikasi staf akuntansi internal berpengaruh positif pada praktik akuntansi manajemen di RKB BRI Kabupaten Gianyar. Pengujian terhadap pengaruh kualifikasi staf akuntansi internal pada praktik akuntansi manajemen dilakukan dengan melihat hasil uji statistik t. Tingkat probabilitas (sig.) $t \quad$ variabel pengalaman adalah $0,000<a=0,05$. $\mathrm{Hal}$ ini menunjukkan bahwa $\mathrm{H}_{3}$ diterima dan $\mathrm{H}_{0}$ ditolak. Kesimpulannya adalah kualifikasi staf akuntansi internal berpengaruh positif pada praktik akuntansi manajemen di RKB BRI Kabupaten Gianyar. Praktik-praktik akuntansi manajemen merupakan salah satu sumber dari informasi keuangan. Berdasarkan Collis dan Jarvis (2002), staf akuntansi internal yang berkualifikasi dan memiliki tingkat pendidikan dan pelatihan mengenai akuntansi yang tinggi akan dapat membantu pengembangan sistem akuntansi manajemen serta analisis dari informasi akuntansi yang 
dihasilkan oleh sistem tersebut. Selain itu, Collis dan Jarvis (2002) juga menemukan bahwa informasi anggaran dan praktik akuntansi kontemporer yang digunakan untuk perencanaan dan pengendalian keuangan juga bergantung pada ketersediaan staf akuntansi internal yang ahli dan profesional. Temuan ini dipertegas pula oleh Marc et al. (2010). Marc et al. menyimpulkan bahwa pengetahuan staf akuntansi internal tentang akuntansi manajemen kontemporer meningkatkan kemungkinan suatu perusahaan untuk menggunakan sistem pengukuran kinerja terintegrasi, seperti misalnya Balanced Scorecard pada UKM di Slovenia. Menurut Sousa et al. (2006) kurangnya keahlian dan pemahaman staf terhadap proses pengukuran kinerja akan menghambat pengadopsian ukuran kinerja baru, terutama yang bersifat nonkeuangan.

Hipotesis ketiga $\left(\mathrm{H}_{4}\right)$ menyatakan bahwa kualifikasi partisipasi pemilik berpengaruh positif pada praktik akuntansi manajemen di RKB BRI Kabupaten Gianyar. Pengujian terhadap pengaruh partisipasi pemilik pada praktik akuntansi manajemen dilakukan dengan melihat hasil uji statistik t. Tingkat probabilitas (sig.) t variabel pengalaman adalah 0,001 < a
$=0,05$. Hal ini menunjukkan bahwa $\mathrm{H}_{4}$ diterima dan $\mathrm{H}_{0}$ ditolak. Kesimpulannya adalah partisipasi pemilik berpengaruh positif pada praktik akuntansi manajemen di RKB BRI Kabupaten Gianyar. Sebagian besar UMKM dimulai dari usaha wiraswasta sehingga pemilik atau manajer memiliki peran utama dalam menentukan kebijakan inovasi UMKM, misalnya dalam pengimplementasian sistem informasi akuntansi. Oleh karena itu, pemilik atau manajer yang berkomitmen merupakan penentu gaya manajemen perusahaan dan penggunaan PAM terbaik yang dapat memberikan informasi manajerial yang tepat, guna membantu pencapaian tujuan strategic perusahaan (Thong et al., 1996). Hal tersebut didukung oleh temuan Ahmad (2012) yang menyebutkan bahwa partisipasi pemilik atau manajer UMKM berpengaruh signifikan dan positif terhadap penggunaan anggaran, sistem pengambilan keputusan, akuntansi manajemen strategik, perencanaan dan pengendalian terutama pada pengembangan strategi. Selain itu, Marn et al. (2016) menemukan bahwa pemilik atau manajer UMKM yang termotivasi oleh pencapaian keuangan dan pengembangan personal menunjukkan penekanan yang tinggi 
pada proses perencanaan strategik. Hal tersebut konsisten dengan literatur yang menyebutkan bahwa pemilik atau manajer perusahaan yang termotivasi oleh keuangan, peningkatan mutu dan ide produk baru, dan pengembangan pribadi cenderung memiliki keinginan atau dorongan yang kuat untuk memajukan usahanya.

Hipotesis ketiga menyatakan bahwa ukuran perusahaan berpengaruh positif pada praktik akuntansi manajemen di RKB BRI Kabupaten Gianyar. Pengujian terhadap ukuran perusahaan pada praktik akuntansi manajemen dilakukan dengan melihat hasil uji statistik t. Tingkat probabilitas (sig.) t variabel ukuran perusahaan adalah 0,000 $<a=0,05$. $\mathrm{Hal}$ ini menunjukkan bahwa $\mathrm{H}_{5}$ diterima dan $\mathrm{H}_{0}$ ditolak. Kesimpulannya adalah ukuran perusahaan berpengaruh positif pada praktik akuntansi manajemen di RKB BRI Kabupaten Gianyar. Temuan ini sesuai dengan penelitian yang dilakukan oleh Ahmad (2012) yang menyebutkan bahwa ukuran perusahaan berhubungan positif dan signifikan dengan penggunaan sistem biaya dan sistem penilaian kinerja pada UMKM. Marc et al. (2010) juga menyebutkan bahwa semakin besar ukuran suatu perusahaan, semakin besar pula kemungkinan UMKM tersebut untuk menggunakan sistem penilaian kinerja terintegrasi. Marc et al. (2010) juga menemukan bila suatu UMKM telah mencapai suatu ukuran tertentu, peningkatan pada ukurannya tidak akan lagi memengaruhi penggunaan sistem penilaian kinerja. Abdel-Kader dan Luther (2008) menemukan bahwa perbedaan pada tingkat kemajuan akuntansi manajemen yang digunakan perusahaan dapat dijelaskan dengan ukuran perusahaan yang bersangkutan. Hansen dan Van der Stede (2004) juga melaporkan bahwa ukuran perusahaan mendorong penggunaan anggaran yang bertujuan untuk penilaian kinerja dan pengomunikasian tujuan perusahaan.

\section{REFERENSI}

Al-Omiri, M., dan C. Drury. 2007. A survey of factors influencing the choice of product costing systems in UK organizations. Management Accounting Research, 18: 399-424.

Armitage, H. M., A. Webb, dan J. Glynn. 2016. The use of management accounting techniques by small and medium-sized enterprises: a field study of Canadian and 
Australian practices. Accounting Perspectives, 15: 31-69.

Chenhall, R. H. 2003. Management control systems design within its organizational context: findings from contingency-based research and directions for the future. Accounting, Organizations and Society, 28: 127-168.

Folk, J. M., H. G. Ray, dan W. N. Eric. 2002. Introduction to Managerial Accounting. New York: McGrawHill.

Halim. 2013. Akuntansi Manajemen. BPFE, Yogyakarta.

Hopper, T., T. Koga, dan J. Goto. 1999. Cost accounting in small and medium sized Japanese companies: an exploratory study. Accounting and Business Research, 30: 73-86.

Ismail, N. A., dan M. King. 2007. Factors influencing the alignment of accounting information systems in small and medium sized Malaysian manufacturing firms. Journal of Information Systems and Small Business, 1: 1-20.

$$
\begin{array}{ccr}
\text { Kamaruddin, } & \multicolumn{2}{c}{\text { 2013.Akuntansi }} \\
\text { Manajemen. } & \text { Edisi } & \text { Revisi, } \\
\text { Cetakan } & \text { Kedelapan. } & \text { Raja } \\
\text { Grafindo, Jakarta } &
\end{array}
$$

Keputusan Menteri Keuangan No. 40/KMK.06/2003 tentang Pendanaan Kredit Usaha Mikro dan Kecil.

Lopez, O. L., dan M. R. W. Hiebl. 2015. Management accounting in small and medium-sized enterprises: current knowledge and avenues for further research. Journal of Management Accounting Research, 27: 81119.
McChlery, S., L. Meechan, dan A. D. Godfrey. 2005. Barriers and catalysts to sound financial management systems in small sized enterprises. CIMA: Research Executive Summaries Serries, 1.

Mutmainah, D. A. 2016. "Kontribusi UMKM terhadap PDB Tembuh Lebih Dari 60 Persen" http://www.cnnindonesia.com/e konomi/20161121122525-92$174080 /$ kontribusi-umkmterhadap-pdbtembus-lebih-dari60-persen/ (accessed April 15, 2017).

Ridha, M. Arsyandi dan Hardi Basuki, 2012. Pengaruh Tekanan Eksternal, Ketidakpastian Lingkungan dan Komitmen Manajemen terhadap Penerapan Transparansi Pelaporan Keuangan. Jurnal Simposium Nasional Akuntansi XV Banjarmasin, 2012

Simamora, Henry. 2013. Akuntansi manajemen, Edisi III. Star Gate Publiser, Jakarta. UndangUndang Republik Indonesia Nomor 20 Tahun 2008 tentang Usaha Mikro, Kecil dan Menengah.

Sousa, S. D., E. M. Aspinwall, P. A. Sampaio, dan A. G. Rodrigues. 2005. Performance measures and quality tools in Portuguese small and medium enterprises: survey results. Total Quality Management, 16: 277-307. 